\title{
PENGARUH PEMBERIAN AIR REBUSAN DAUN SALAM (Syzigium polyanthum) TERHADAP PENURUNAN TEKANAN DARAH PADA PENDERITA HIPERTENSI DI LINGKUNGAN I KELURAHAN SEI AGUL TAHUN 2018
}

\author{
Eva Latifah Nurhayati ${ }^{1}$, Muslim Yanis Lubis ${ }^{2}$ \\ Universitas Prima Indonesia, Fakultas Keperawatan dan Kebidanan, Jl. Danau Singkarak Gg. Madrasah, Kelurahan Sei \\ Agul Kecamatan Medan Barat
}

\begin{abstract}
Abstrak
Hipertensi merupakan penyakit kronik menahun, hipertensi dapat merusak jantung, ginjal, otak dan organ lain sehingga menyebabkan kelainan dan kematian. Prevalensi hipertensi di Indonesia sebesar 34,9\%. Hipertensi disebut sebagai "silent killer" karna tidak ada gejala atau tanda khas. Salah satu pengobatan hipertensi yaitu dengan pemberian rebusan daun salam. Daun salam mengandung senyawa flavonoid yang dapat menurunkan tekanan darah. Penelitian ini bersifat pre eksperiment dengan desain one group pre-post test dengan menggunakan Uji Wilcoxon, sampel adalah penderita hipertensi di Lingkungan 1 Kelurahan Sei Agul, sebanyak 63 orang. Dari hasil penelitian ini menunjukkan tekanan darah pada hari ke 7 sebelum dilakukan pemberian rebusan air daun salam (pre test) rata-rata tekanan darah 1,58 dengan standart deviasi ,504. Sedangkan tekanan darah setelah dilakukan pemberian rebusan air daun salam (post test) rata-rata tekanan darah 1,08 dengan standart deviasi ,272. Berdasarkan uji statistik wilxocon didapatkan p value 0,000 $(<0,05)$ secara statistik ada pengaruh yang signifikan. Dapat ditarik kesimpulan bahwa ada penurunan tekanan darah pada penderita hipertensi pemberian rebusan air daun salam sebelum dan sesudah pemberian air rebusan daun salam.
\end{abstract}

Kata kunci :

\section{PENDAHULUAN}

Penyakit degeneratif merupakan penyakit kronik menahun yang banyak mempengaruhi kualitas hidup serta produktivitas seseorang. Penyakit-penyakit degeneratif tersebut antara lain penyakit kardiovaskuler (jantung dan pembuluh darah) termasuk hipertensi, diabetes mellitus dan kanker (Brunner \& Suddarth, 2002).

Salah satu penyakit degeneratif yang banyak terjadi dan yang mempunyai tingkat mortalitas yang cukup tinggi serta yang mempengaruhi kualitas hidup dan produktivitas seseorang salah satunya penyakit hipertensi. Hipertensi adalah suatu keadaan dimana di jumpai tekanan darah lebih dari 140/90 mmHg atau lebih untuk usia 13-50 tahun dan tekanan darah mencapai 160/95 mmHg untuk usia di atas 50 tahun (Wijaya, 2009).

Berdasarkan data World Health Organization (WHO) Tahun 2015, persentase dari populasi yang berumur di atas 18 tahun ke atas pada tahun 2014 yang mengalami peningkatan tekanan darah (tekanan darah sistolik $\geq 140 \mathrm{mmHg}$ atau tekanan darah diastolik $\geq 90$ mmHg) yaitu 24,0\% pada laki-laki dan 20,5\% pada wanita. Menurut WHO dan The International Society Of Hypertension (ISH), saat ini terdapat 600 juta penderita hipertensi diseluruh dunia, dan 3 juta di antaranya meninggal setiap tahunnya.
Berdasarkan hasil pengukuran Riskesdas tahun (2007), dinyatakan bahwa prevalensi penyakit hipertensi di Indonesia sebesar 34,9\%. Dan hasil survei kesehatan rumah tangga (SKRT) tahun 2004, prevalensi hipertensi di Indonesia sekitar 14\%, prevalensi hipertensi meningkat dengan bertambah usia, pada kelompok umur 25-34 tahun sebesar 7\%. Jumlah meningkat menjadi 16\% pada kelompok umur 33-44 tahun meningkat lagi menjadi 29\% pada kelompok umur 60 tahun atau lebih. Prevalensi tersebut pada perempuan (16\%) lebih tinggi dari pada lakilaki (12\%) (Junaedi, 2013).

Berdasarkan data dinas kesehatan Sumatra Utara (2017), tercatat sebanyak 50.162 orang menderita hipertensi, pada data tersebut tercatat paling banyak yang menderita hipertensi adalah wanita dengan jumlah 27.021 orang penderita hipertensi. Untuk usia yang paling banyak menderita hipertensi adalah usia diatas 55 tahun dengan jumlah 22.618 orang, kemudian usia 18 sampai 44 tahun dengan dengan jumlah 14.984 orang dan usia 45 sampai 55 tahun dengan jumlah 12.560 orang. Sementara untuk daerah yang paling banyak penderita hipertensi yang terlihat dari data itu adalah Langkat dengan jumlah 6.643 orang, kemudian Dairi dengan jumlah 5.652 orang, Asahan dengan jumlah 5.421 orang, dan Pematang Siantar dengan jumlah 4.055 orang menderita hipertensi. 
Budewi (2011), mengatakan selain obat-obatan farmakologi dan non-fakmakologi untuk penanganan hipertensi, juga terdapat obat-obat yang berasal dari bahan herbal, yaitu dari tanaman obat. Salah satunya adalah daun salam, salam sengaja di tanam untuk diambil daunya, daun inilah yang kemudian dimanfaatkan sebagai salah satu untuk pengobatan tradisional, dan salah satu bumbu dalam berbagai masakan khas Indonesia.

Salam (Syzgiyum polyanthum) adalah nama pohon penghasil daun rempah yang banyak digunakan dalam masakan Indonesia. Obat tradisional ini secara empiris berkhasiat dalam terapi hipertensi. Daun salam tumbuh menyebar di Asia Tenggara dan sering di temukan dipekarangan rumah. Selain sebagai bumbu dapur, daun salam memiliki banyak manfat untuk kesehatan misalnya untuk mengobati diabetes militus, gastritis, pruritus, diare, mabuk karena alkohol, dan hipertensi. (Agoes, 2010).

Berdasarkan penelitian Yunus (2015), daun salam mengandung senyawa flavonoid, yang mana flavonoid mengandung quarcertin memberikan pengaruh sebagai vasolidator, antipletelet, dan antipoliferative dan menurunkan tekanan darah, hasil dari oksidasi dan perbaikan terhadap organ tubuh yang sudah rusak akibat dari hipertensi. Dengan demikian disimpulkan bahwa flavonoid dapat digunakan untuk menekan resiko terjadinya miokardiak infark dan stroke.

Menurut Savitri (2016), kandungan mineral yang ada pada daun salam membuat peredaran darah menjadi lebih lancar dan mengurangi tekanan darah tinggi daun salam juga mengandung minyak esensial eugenol dan metal kavikol, serta etanol yang berperan aktif sebagai anti jamur dan bakteri. Kandungan kimiawi dari daun salam terdiri dari berbagai senyawa kimia, seperti Saponin, Triterpen, Flavonoid, Tannin, Alkaloid minyak Atsiri (Seskuiterpen, lakton, dan Fenol).

Berdasarkan survei awal yang dilakukan oleh peneliti di Lingkungan 1 Kelurahan Sei Agul pada bulan November 2017, jumlah penduduk saat ini 1.498 jiwa terdiri dari 789 orang pria dan 709 orang wanita. Terdapat 63 orang yang menderita hipertensi, dimana yang paling banyak penderita hipertensi adalah umur 35-60 tahun. Upaya yang dilakukan dalam penanganan hipertensi dengan cara pengobatan farmakologi dan non-farmakologi, beberapa warga juga melakukan pengobatan ke sarana kesehatan seperti puskesmas, rumah sakit. Pengobatan atau tindakan seperti pemberian rebusan air daun salam belum dilakukan di Lingkungan 1 Kelurahan Sei Agul, dan masih banyak warga Lingkungan 1 Kelurahan Sei Agul yang belum mengetahui khasiat daun salam dalam menurunkan tekanan darah, warga hanya mengetahui daun salam bermaanfat sebagai bumbu masakan.

\section{METODE}

\section{Jenis Dan Desain Penelitian}

Jenis penelitian ini adalah penelitian praeksperiment dengan menggunakan rancangan one-group pretest posttest design. Dalam penelitian ini dilakukan 2 kali pengukuran tekanan darah, yaitu pada saat sebelum pemberian air rebusan daun salam dan sesudah pemberian air rebusan daun salam pada penderita hipertensi di Lingkungan I Kelurahan Sei Agul

\section{Populasi dan Sampel Penelitian}

Menurut Soekidjo Notoadmojo bahwa populasi adalah keseluruhan subjek penelitian. Populasi dalam penelitian ini adalah seluruh penderita yang menderita hipertensi atau tekanan darah tinggi di Lingkungan 1 Kelurahan Sei Agul sebanyak 26 orang.

Sampel adalah sebagian yang diambil dari keseluruhan objek yang akan diteliti dianggap mewakili seluruh populasi (Arikunto: 2006)Teknik pengambilan sampel dalam penelitian ini adalah dengan sampling jenuh yaitu keseluruhan populasi dijadikan sampel. Sampel dari penelitian ini adalah 26 orang yang menderita hipertensidi Lingkungan I Kelurahan Sei Agul.

\section{HASIL}

\section{Hasil Penelitian}

\subsection{Analisis Univariat}

Data yang dikumpulkan adalah data hasil penelitian yang dilakukan terhadap penderita hipertensi di Lingkungan I kelurahan Sei Agul Kecamatan Medan Barat. Penelitian langsung dilakukan kepada penderita hipertensi dengan memberikan dua kali pengukuran tekanan darah sebelum dan sesudah pemberian air rebusan daun salam Setelah data terkumpul, dibuatlah analisis data dengan cara membuat tabel distribusi frekuensi untuk masing-masing kelompok sampel. Kemudian dilakukan pengolahan data statistik yaitu dengan mengunakan Uji Wilcoxon.

Tabel 4.1 Distribusi frekuensi pemberian air rebusan daun salam terhadap penurunan tekanan darah pada penderita hipertensi berdasarkan pre test responden pada hari 1 - hari ke 7.

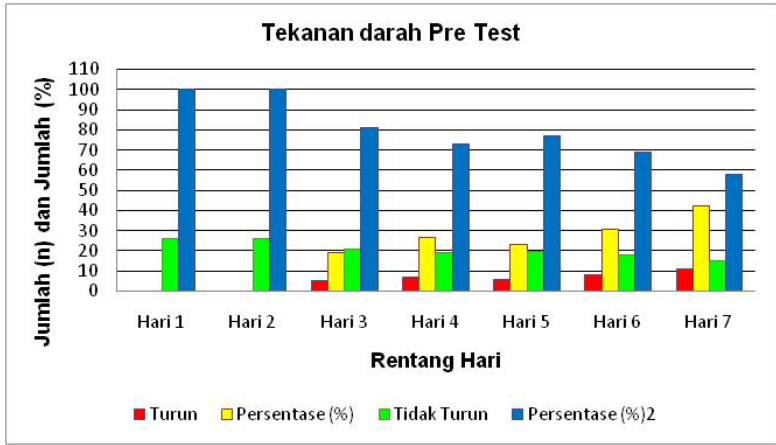

Diagram diatas menunjukan bahwa dari 26 orang responden sebagian besar yang mengalami penurunan tekanan darah sebelum pemberian air rebusan daun salam terjadi pada hari ke 7 sebanyak 11 orang (42,3\%). 
Tabel 4.2. Distribusi frekuensi pemberian rebusan daun salam terhadap penurunan tekanan darah pada penderita hipertensi berdasarkan post test responden pada hari 1 - hari ke 7

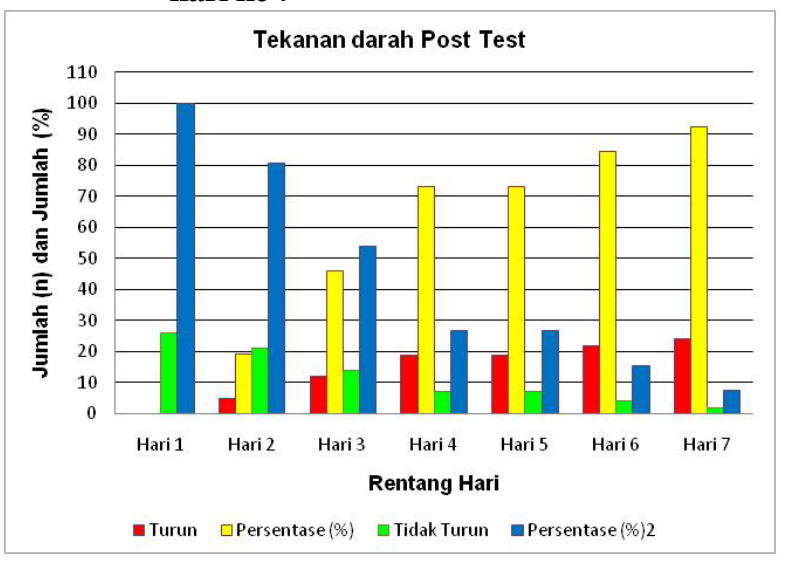

Diagram diatas menunjukan bahwa dari 26 orang responden sebagian besar yang mengalami penurunan tekanan darah sesudah pemberian air rebusan daun salam terjadi pada hari ke 7 sebanyak 24 orang 92,3\%)

\section{Analisis Bivariat}

Analisa bivariat dilakukan untuk melihat pengaruh pemberian rebusan air daun salam terhadap penurunan tekanan darah pada penderita hipertensi

\begin{tabular}{|c|c|c|c|c|c|c|c|}
\hline \multirow{2}{*}{$\begin{array}{l}\text { Pemberian } \\
\text { rebusan air } \\
\text { daun salam }\end{array}$} & \multicolumn{2}{|c|}{ Tekanan darah } & \multirow[b]{2}{*}{$\mathrm{N}$} & \multirow[b]{2}{*}{ Mean } & \multirow{2}{*}{$\begin{array}{c}\text { Std. } \\
\text { deviation }\end{array}$} & \multirow[b]{2}{*}{$Z$} & \multirow{2}{*}{$\begin{array}{c}\mathrm{P} \text { - } \\
\text { value }\end{array}$} \\
\hline & Turun & $\begin{array}{l}\text { Tidak } \\
\text { Turun }\end{array}$ & & & & & \\
\hline \multicolumn{8}{|l|}{ Hari ke 1} \\
\hline Pre Test & 0 & 26 & 26 & 2,00 & ,000 & \multirow{2}{*}{,000 } & \multirow{2}{*}{1,000} \\
\hline Post test & 0 & 26 & 26 & 2,00 & ,000 & & \\
\hline \multicolumn{8}{|l|}{ Hari ke 2} \\
\hline Pre test & 0 & 26 & 26 & 2,00 &, 000 & \multirow[t]{2}{*}{$-2,236$} & \multirow[t]{2}{*}{,025 } \\
\hline Post test & 5 & 21 & 26 & 1,81 &, 402 & & \\
\hline \multicolumn{8}{|l|}{ Hari ke 3} \\
\hline Pre test & 5 & 21 & 26 & 1,81 &, 402 & \multirow{2}{*}{$-2,646$} & \multirow{2}{*}{, 008} \\
\hline Post test & 12 & 14 & 26 & 1,54 &, 508 & & \\
\hline \multicolumn{8}{|l|}{ Hari ke 4} \\
\hline Pre test & 7 & 19 & 26 & 1,73 &, 452 & \multirow{2}{*}{$-2,683$} & \multirow{2}{*}{, 007} \\
\hline Post test & 19 & 7 & 26 & 1,27 &, 452 & & \\
\hline \multicolumn{8}{|l|}{ Hari ke 5} \\
\hline Pre test & 6 & 20 & 26 & 1,27 &, 430 & \multirow{2}{*}{$-2,982$} & \multirow{2}{*}{, 003} \\
\hline Post test & 19 & 7 & 26 & 1,77 &, 452 & & \\
\hline \multicolumn{8}{|l|}{ Hari ke 6} \\
\hline Pre test & 8 & 18 & 26 & 1,69 &, 471 & \multirow{2}{*}{$-2,985$} & \multirow{2}{*}{,003 } \\
\hline Post test & 22 & 4 & 26 & 1,15 &, 368 & & \\
\hline \multicolumn{8}{|l|}{ Hari ke 7} \\
\hline Pre test & 11 & 15 & 26 & 1,58 &, 504 & \multirow{2}{*}{$-3,606$} & \multirow{2}{*}{, 000} \\
\hline Post test & 24 & 2 & 26 & 1,08 &, 272 & & \\
\hline
\end{tabular}

\section{PEMBAHASAN}

Berdasarkan hasil analisis statistik pengaruh pemberian rebusan daun salam terhadap penurunan tekanan darah, dengan jumlah responden 26 orang, sebelum (pre test) dilakukan pemberian air rebusan daun salam, diperoleh rata-rata tekanan darah pada hari ke 1 ,
$(2,00)$ dengan standart deviasi $(, 000)$ dan setelah (post test) dilakukan pemberian rebusan daun salam diperoleh ratarata tekanan darah $(2,00)$ dengan standart deviasi $(, 000)$, dan pada hari ke 2 sebelum (pre test) dilakukan pemberian air rebusan daun salam diperoleh rata rata tekanan darah $(2,00)$ dengan standart deviasi $(, 000)$, dan setelah (post test) dilakukan pemberian air rebusan daun salam diperoleh rata-rata tekanan darah $(1,81)$ dengan standart deviasi (,402), dan pada hari ke 3 sebelum (pre test) dilakukan pemberian air rebusan daun salam diperoleh rata-rata tekanan darah $(1,81)$ dengan standart deviasi $(, 402)$ dan setelah (post test) dilakukan pemberian air rebusan daun salam diperoleh rata rata tekanan darah $(1,54)$ dengan standart deviasi $(, 508)$. Dan pada hari ke 4 sebelum (pre test) dilakukan pemberian air rebusan daun salam diperoleh rata-rata tekanan darah (1.73) dengan standart deviasi $(457)$ dan setelah (post test) diperoleh rata-rata $(1,27)$ dengan standart deviasi $(, 452)$, dan pada hari ke 5 sebelum (pre test) dilakukan pemberian air rebusan daun salam diperoleh rata-rata tekanan darah $(1,27)$ dengan standart deviasi $(, 430)$ dan setelah (post test) diperoleh ratarata tekanan darah $(1,77)$, dengan standart deviasi $(, 450)$, dan pada hari ke 6 sebelum (pre test) dilakukan pemberian air rebusan daun salam diperoleh rata-rata tekanan darah $(1,69)$ dengan standart deviasi $(471)$ dan setelah (post test) dilakukan pemberian air rebusan daun salam diperoleh rata-rata tekanan darah $(1,15)$ dengan standart deviasi (,368), dan pada hari ke 7 sebelum (pre test) dilakukan pemberian air rebusan daun salam diperoleh rata-rata tekanan darah $(1,58)$ dengan standart deviasi $(, 504)$ dan setelah (post test) pemberian air rebusan daun salam diperoleh rat-rata tekanan darah $(1,08)$ dengan srandart deviasi (,172). Berdasarkan hasil perhitungan Wilxocon signed rank test, hari ke 1 , diperoleh nilai $\mathrm{Z}, 000$ dengan pvalue 1,000 maka H0 diterima, dan pada hari ke 2, diperoleh nilai $\mathrm{Z}$-2,236 denngan p-value 0,025 maka H0 diterima, dan pada hari ke 3, diperoleh nilai Z -2,646 dengan p-value 0,008 maka H0 di terima, pada hari ke 4, diperoleh nilai $\mathrm{Z}-2,683$ dengn $\mathrm{p}$-value 0,007 maka H0 diterima, dan pada hari ke 5, diperoleh nilai Z -2,982 dengan p-value 0,003 maka Ha diterima, dan pada hari ke 6, diperoleh nilai $\mathrm{Z}-2,985$ dengan $\mathrm{p}$-value 0,003 maka Ha diterima, dan pada hari ke 7 diperoleh nilai Z -3,606 dengan p-value 0,000 maka Ha diterima. Disimpulkan bahwa ada pengaruh pemberian air rebusan daun salam terhadap penurunan tekanan darah pada penderita hipertensi tahun 2018.

Hasil penelitian ini sejalan dengan penelitian Putri Dafriani di Sungai Bungkal, Kerinci tahun 2016, tentang pengaruh rebusan daun salam (syzigium polyanthum wight walp) terhadap tekanan darah pasien hipertensi, menunjukan secara keseluruhan ada pengaruh antara tekanan darah sebelum dan sesudah di berikan pemberian rebusan daun salam dengan menujukan perubahan tekanan darah pre-test dan Post- Test dengan hasil uji statistik t-test didapatkan p-value $0.000<(0.05)$ yang berarti ada pengaruh antara tekanan darah sebelum dan sesudah pemberian air rebusan daun salam.

Menurut asumsi peneliti sendiri sesuai dengan teori bahwa pemberian air rebusan daun salam 
dapat menurunkan tekanan darah, karna daun salam mengandung senyawa flavonoid yang berpengaruh sebagai vasolidator pembuluh darah. Hal ini dapat di lihat bahwa dari 26 responden setelah mengkonsumsi rebusan air daun salam 2 kali sehari sebanyak setengah gelas pada hari ke 1, tidak ada yang mengalami penurunan tekanan darah, hari ke 2 sebanyak 5 orang $(19,2 \%)$ dari responden mengalami penurunan tekanan darah, hari ke 3 sebanyak 12 orang (46,2\%), pada hari ke 4 sebanyak 19 orang $(73,1 \%)$, pada hari ke 5 sebanyak 19 orang $(73,1 \%)$, pada ke hari 6 sebanyak 22 orang $(84,6 \%)$, pada hari ke 7 sebanyak 24 orang dari responden yang mengalami penurunan tekanan darah (92,3\%).

\section{SIMPULAN}

1. Sebelum dilakukan pemberian air rebusan daun salam (pre test), rata-rata tekanan darah responden pada hari ke 1 adalah (2,00),rata-rata tekanan darah responden pada hari ke $2(2,00)$, rata-rata tekanan darah responden pada hari ke $3(1,81)$, rata-rata tekanan darah responden pada hari ke $4(1,73)$, rata-rata tekanan darah responden pada hari ke 5 $(1,27)$, rata-rata tekanan darah responden pada hari ke 6 (1,69),dan rata-rata tekanan darah reponden hari ke $7(1,58)$ Nilai rata-rata skor pengetahuan sesudah penyuluhan kesehatan gigi dan mulut dengan metode ceramah dan bermain adalah 13 dan 14,3.

2. Sesudah dilakukan pengaruh pemberian air rebusan daun salam (post test), rata-rata tekanan darah responden pada hari ke 1 adalah $(2,00)$, ratarata tekanan darah responden pada hari ke $2(1,81)$, rata-rata tekanan darah responden pada dari ke 3 (1,54), rata-rata tekanan darah pada hari ke 4 (1,27), rata-rata tekanan darah pada hari ke 5 (1,77), rata-rata tekanan darah pada hari ke 6 $(1,15)$, dan rata-rata tekanan darah pada hari ke 7 $(1,08)$

3. Ada pengaruh pemberian air rebusan daun salam terhadap penurunan tekanan darah pada penderita hipertensi di Lingkungan I Kelurahan Sei Agul Tahun 2018, dengan nilai p-value hari $1=1,000$, nilai $\mathrm{p}$-value hari ke $2=0,025$, nilai $\mathrm{p}$-value hari ke $3=0,08$, nilai $p$-value hari ke $4=0,007$, nilai $p$-value hari ke $5=0,003$, nilai $p$-value hari ke $6=0,003$, dan nilai p-value hari ke $7=0,000$.

\section{SARAN}

1. Penelitian ini agar dapat dimanfaatkan untuk meningkatkan pelayanan kesehatan pada penderita hipertensi, khususnya nya di Lingkungan I Kelurahan Sei Agul tahu 2018

2. diharapkan responden di Lingkungan I Kelurahan Sei Agul tahun 2018, agar dapat menjadikan pemberian air rebusan daun salam sebagai salah satu obat alternatif untuk menurun kan tekanan darah pada penderita hipertensi.

\section{DAFTAR PUSTAKA}

Rusli M, Gondhoyoewono T, 2003. Pengaruh metode bermain terhadap penyuluhan kesehatan gigi dan mulut ( the effect of role playing method to dental health education). Fakultas Kedokteran Gigi. Jakarta.

Alwi, Q. 2014. Hubungan Pengetahuan dan Sikap Lansia Dengan Kejadian Hipertensi Di Puskesmas Kecamatan Pondok Gede Kota Bekasi, Jurnal Kesehatan Persada Husada Indonesia, Vol. 1, No. 3, hal. 2, Juni 2014.

Apriyanti, Maya. 2012. Meracik Sendiri Obat \& Menu Sehat Bagi Penderita Hipertensi, cetakan. 1, Pustaka Baru Press, Yogyakarta.

Dafriani, P. 2016. Pengaruh Rebusan Daun Salam (Syzigium polyanthum) Terhadap Tekanan Darah Pasien Hipertensi Di Sungai Bungkal Kerinci. Jurnal Medika Saintika, Vol. 7, No. 2, Hal. 25-27, Desember 2016.

Hasdianah, Siyoto, S., Indasah, Wardani, R. 2015. Buku Ajar Dasar-Dasar Riset Keperawatan, Cetakan. 1, Nuha Medika, Yogyakarta.

Junaedi, E.,Yulianti, S., Rinata, G.M., 2013. Hipertensi Kandas Berkat Herbal, cetakan. 1, Media (Imprint Agromedia Pustaka), Jakarta.

Masriadi, H. 2016. Epidemiologi Penyakit Tidak Menular, cetakan. 1, CV. TRANS INFO MEDIA, Jakarta.

Notoatmodjo, Soekidjo. 2012. Metodelogi Penelitian Kesehatan, cetakan. 1, PT RINEKA CIPTA, Jakarta.

Nucahyati, Erna. 2014. Khasiat Dadsyat Daun Salam untuk Kesehatan \& Pengobatan Tanpa Efek samping, Cetakan. 1, PT. Serambi Distribusi, Jakarta.

Rahajeng, E., dan, Tuminah, sulistyowati. 2009. Prevalensi Hipertensi dan Determinannya Di Indonesia, Maj kedokt Indon, Vol: 59, No: 12, Desember 2009.

Romauli. 2007. Pengaruh Gaya Hidup Terhadap Kejadian Hipertensi Di RSUD. H. kompula Pane Tebing Tinggi, Jurnal Sumantek, Vol: 1, No: 2, Juni 2017.

Sanjaya, pengertian tekanan darah, mekanisme, pemeliharaan, pengukuran, dan gangguan, 21/09/2015 www.landasanteori.com.

Tamsuri, T., Chamida N.Y.A., 2013. Pengaruh Rebusan Daun Salam Terhadap Penurunan Tekanan Darah Pada Pasien Hipertensi, Jurnal AKP, Vol. 4, No. 2, 1 Juli-3 Desember 2013.

Utami, Prapti, dan Puspaningtyas, E.D., 2013. The Miracle Herbs, Cetakan. 1, PT Agromedia Pustaka, Jakarta

Yulianti, S., Setyaningsih, R., dan Suryaningsih., M. 2014 Pengaruh Rebusan Air Rebusan Daun Salam Terhadap Penurunan Tekanan Darah Pada Penderita Hipertensi Di Dukuh Jangkung Rejo Nogosari Boyolali, Kosala, Vol. 2, No. 2, September 2014.

Wade Carlson, 2017. Mengatasi Hipertensi, Cetakan. 2, Nuansa Cendika, Bandung. 